\title{
Microirrigation Equipment for Okra Cultivation in the U.S. Virgin Islands
}

\author{
Rhuanito Soranz Ferrarezi \\ University of Florida, Institute of Food and Agricultural Sciences, Indian \\ River Research and Education Center, 2199 South Rock Road, Fort Pierce, \\ FL 34945
}

\author{
Thomas C. Geiger, Jayar Greenidge, Shamali Dennery, \\ and Stuart A. Weiss \\ University of the Virgin Islands, Agricultural Experiment Station, RR\#1 Box \\ 10,000, Kingshill, U.S. Virgin Islands 00850
}

\section{Gustavo H.S. Vieira \\ Instituto Federal do Espírito Santo, Campus Santa Teresa, Rod. ES $080 \mathrm{~km}$ 93, S.J. Petropolis, Santa Teresa, ES, Brazil 29.660-000}

Additional index words. drip irrigation, irrigation efficiency, tropics, variety trial, water-saving technologies

\begin{abstract}
Drip irrigation presents higher distribution efficiency than sprinkler irrigation. Proper system design and the use of pressure-compensating emitters have important roles in irrigation uniformity and efficiency, which directly affect plant growth. This study evaluated the performance of four pressure-compensating and noncompensating emitters and the effects of these irrigation equipment on the yield of three okra [Abelmoschus esculentus] varieties cultivated in the U.S. Virgin Islands. Trials were performed in two seasons (Spring and Fall 2016), and tested four types of irrigation equipment (flow control drip tape, thin wall drip line, thin wall drip tape, and heavy wall drip line) and three varieties of okra ('Clemson Spineless 80', 'Clemson Spineless', and 'Chant'), arranged on a complete randomized block design with three replications. Irrigation was performed based on reference evapotranspiration and measured daily using an automated weather station. Soil moisture, electrical conductivity (EC), and soil temperature were monitored using capacitance sensors. The ability of the irrigation equipment to increase pressure was evaluated in the laboratory, in experimental modules using clean water, and while simulating three different slopes (leveled, uphill, and downhill). In the field trial, yield and leaf physiological parameters were influenced by season $(P<0.05)$ and the percentage of the marketable yield was influenced by variety $(P<0.05)$; however, fruit morphological parameters and soluble solids content were variety-dependent $(P<0.01)$. The pressure-compensating emitters maintained water flow within the range indicated by the manufacturers when used within the recommended pressure range. Distribution uniformity decreased over time for all equipment except the heavy wall drip line in Fall 2016. Irrigation equipment did not impact okra morphological attributes and yield, indicating that the same productivity can be successfully maintained while improving irrigation efficiency. Equipment should be selected based on price and irrigation efficiency to reduce the amount of water used.
\end{abstract}

Agriculture uses the majority of the potable water available on the planet, with irrigation accounting for $70 \%$ of global water withdrawals. The irrigation equipment used has an important role in water use and irrigation efficiency. For an irrigation system to be considered efficient, water distribution needs to be uniform within the line $(\approx 10 \%)$, and pressure variation across the secondary line should be lower than $20 \%$ (Burt et al., 1997). After installing the irrigation system, growers must ensure it matches the project design in the field. Pressure, water flow and distribution, and efficiency coefficients are necessary to evaluate system performance (Silva and Silva, 2005).

Drip irrigation has become one of the most common systems used for agriculture due to the potential for high irrigation effi- sources (Palada et al., 1995). Since then, farmers shifted from sprinkler to drip irrigation (also known as microirrigation). However, most of the U.S. Virgin Islands local farmers use drip tapes with noncompensating emitters. The water output of nonpressurecompensating emitters varies as the line pressure changes, which may result in inefficient water application $(<70 \%)$ (Dogan and Kirnak, 2010). Pressure-compensating emitters apply the same amount of water at each emitter over a range of different line pressures (i.e., 70-350 kPa). These emitters can be used in long lines, irregular or mountainous areas, and where precise watering is desired (Dogan and Kirnak, 2010). When water resources become limited, especially during years affected by severe drought, as occurred in 2015 in the U.S. Virgin Islands and California, it is necessary to improve irrigation management and equipment efficiency to save water and pumping energy.

The performance evaluation of drip irrigation systems is simple, and instructions and results are widely available in the literature (Pereira et al., 2012). However, few farmers run performance tests regularly. This is mainly due to the lack of knowledge about the importance of managing irrigation systems properly. Consequences include reduced crop yields and wasted water resources. To improve irrigation performance, it is necessary to promote the use of irrigation scheduling methods, improve system design and equipment performance, and enhance farmers' skills to manage irrigation systems efficiently (Pereira et al., 2002).

Okra (Abelmoschus esculentus) is one of the most important and widely grown crops found throughout the tropical and subtropical regions (Eshiet and Brisibe, 2015). It is an annual, erect-growing, high-yielding crop with numerous cultivars varying in plant height, degree of branching, pigmentation of the various parts, period of maturity, and pod shape and size. Okra is mainly grown for its tender green pods, which are cooked and commonly consumed as boiled vegetables. Despite its enormous economic benefits, okra rarely reaches its maximum yield potential due to several constraints (Eshiet and Brisibe, 2015). Some of the major factors limiting okra production include the use of locally unimproved varieties, high incidence of pests and diseases, a narrow genetic base of existing varieties, and lack of proper irrigation to control plant growth.

Driven by the desire to indicate the best irrigation equipment for local growers to save water and select more adapted genotypes in okra, the objective of the current study was to determine the performance of four pressurecompensating and noncompensating emitters and the effects of these irrigation equipment types on the yield of three okra varieties cultivated in the U.S. Virgin Islands.

\section{Materials and Methods}

Location. Trials were conducted from 24 Mar. to 11 July 2016 (Spring) and from 12 
Aug. to 1 Dec. 2016 (Fall) at the Agricultural Experiment Station of the University of the Virgin Islands in Kingshill, U.S. Virgin Islands (lat. $17^{\circ} 43^{\prime} 08^{\prime \prime} \mathrm{N}$, long. 64 $47^{\prime} 46^{\prime \prime} \mathrm{W}$, $30 \mathrm{~m}$ above sea level). The study site was located in St. Croix, which is the largest island of the U.S. Virgin Islands territory. The overall climatic conditions of this $\mathrm{Ca}$ ribbean island are described in Ferrarezi et al. (2016).

Soil. The soil of the experimental site was a Sion clay $(\mathrm{SiB})$ with $2 \%$ to $5 \%$ slope according to the U.S. Department of Agriculture soil survey (USDA, 2015). Samples used to determine soil nutrient concentrations were collected $\approx 15 \mathrm{~d}$ prior to transplanting for both seasons. Results are available in Table 1.

Environmental conditions. Environmental data were recorded throughout the trials using an automated weather station (ET107; Campbell Scientific, Logan, UT). The equipment was located $50 \mathrm{~m}$ from the experiment site and measured wind speed and direction, rainfall, air temperature, relative humidity, and solar radiation. The vapor pressure deficit was calculated from the saturated and actual air vapor pressures using the air temperature and relative humidity data (Fig. 1). The temperature was regular during the crop cycles; it did not present significant variations. In the Fall, it rained $23 \%$ more than it did in the Spring. The greatest rainfall values were observed $\approx 40 \mathrm{~d}$ after transplant (DAT) in Spring $(363 \mathrm{~mm})$ and after 80 DAT in Fall (447 mm).

Received for publication 17 Mar. 2020. Accepted for publication 30 Apr. 2020.

Published online 4 June 2020.

We thank Victor Almodovar and Naima Jenkins-El [University of the Virgin Islands' (UVI) Agricultural Experiment Station (AES), Horticulture and Aquaculture program], Jose Herrera, K. Paul Beamer, Ephraim Rodriguez, and Nelson Benitez (UVI-AES Agronomy program), Jordan Atemazem, and high school students Nhaquifa Russell, Vernon Sackey, and Danah Suarez for their technical assistance.

Funding for this research was provided by the U.S. Department of Agriculture (USDA) National Institute of Food and Agriculture (NIFA) Hatch Funds (accession no. 227355 and 1010280), USDA-NIFA Hatch/Multi State W3128 "Scaling Microirrigation Technologies to Address the Global Water Challenge" (accession no. 1006963 and 1015783), and USDA-NIFA Hatch/Multi State W4128 "Microirrigation: A Sustainable Technology for Crop Intensification and Improved Crop Productivity" (accession no. 1021596). Funding for Dr. Vieira was provided by Prodif (Institutional Scientific Diffusion Program) and the Federal Institute of Education, Science, and Technology of Espírito Santo, Brazil.

Mention of trade names or commercial products in this publication is solely for the purpose of providing specific information and does not imply recommendation or endorsement by the authors.

R.S.F. is the corresponding author. E-mail: rferrarezi@ ufl.edu.

This is an open access article distributed under the CC BY-NC-ND license (https://creativecommons. org/licenses/by-nc-nd/4.0/).
Treatments. We tested four different drip irrigation equipment fflow control drip tape [Toro Aqua-Traxx FC; The Toro Company, El Cajon, CA] $\left(1.02 \mathrm{~L} \cdot \mathrm{h}^{-1}\right.$ at $69 \mathrm{kPa}$ according to the manufacturer's catalogue), thin wall drip tape [Jain Turbo Top Thin Wall PC; Jain Irrigation Systems Ltd., Columbus, $\mathrm{OH}]\left(0.98 \mathrm{~L} \cdot \mathrm{h}^{-1}\right.$ at $\left.83 \mathrm{kPa}\right)$, heavy wall drip

line [Netafim Dripnet PC; Netafim, Fresno, $\mathrm{CA}]\left(0.98 \mathrm{~L} \cdot \mathrm{h}^{-1}\right.$ at $\left.83 \mathrm{kPa}\right)$, and thin wall drip line [Classic Thinwall Dripline; Eurodrip USA, Madera, CA] $\left(0.94 \mathrm{~L} \cdot \mathrm{h}^{-1}\right.$ at $\left.\left.83 \mathrm{kPa}\right)\right\}$ and three okra varieties ('Clemson Spineless 80', 'Clemson Spineless', and 'Chant'), for a total of 12 treatments and three replications (36 experimental units). We used one drip

Table 1. Nutrient concentration of Sion clay soil in Spring and Fall 2016. Kingshill, U.S. Virgin Islands. ${ }^{2}$

\begin{tabular}{|c|c|c|}
\hline Nutrient & Spring & Fall \\
\hline Soil pH & 7.6 & 7.7 \\
\hline Nitrate nitrogen $\left(\mathrm{N}-\mathrm{NO}_{3}\right), \mathrm{kg} \cdot \mathrm{ha}^{-1}$ & 44.8 & 59.0 \\
\hline Ammonium nitrogen $\left(\mathrm{N}-\mathrm{NH}_{4}\right), \mathrm{kg} \cdot \mathrm{ha}^{-1}$ & 61.3 & 5.3 \\
\hline Phosphorus (P), $\mathrm{kg} \cdot \mathrm{ha}^{-1}$ & 69.4 & 103.8 \\
\hline Potassium $(\mathrm{K}), \mathrm{kg} \cdot \mathrm{ha}^{-1}$ & 688.5 & $1,132.0$ \\
\hline Calcium (Ca), $\mathrm{kg} \cdot \mathrm{ha}^{-1}$ & $19,232.6$ & $25,825.0$ \\
\hline Magnesium (Mg), $\mathrm{kg} \cdot \mathrm{ha}^{-1}$ & 685.4 & 802.7 \\
\hline Sulfur (S), $\mathrm{kg} \cdot \mathrm{ha}^{-1}$ & 64.2 & 85.1 \\
\hline Boron (B), $\mathrm{kg} \cdot \mathrm{ha}^{-1}$ & 5.0 & 6.6 \\
\hline Copper $(\mathrm{Cu}), \mathrm{kg} \cdot \mathrm{ha}^{-1}$ & 5.2 & 7.2 \\
\hline Iron $(\mathrm{Fe}), \mathrm{kg} \cdot \mathrm{ha}^{-1}$ & 73.9 & 42.6 \\
\hline Manganese $(\mathrm{Mn}), \mathrm{kg} \cdot \mathrm{ha}^{-1}$ & 67.2 & 85.9 \\
\hline Zinc (Zn), kg.ha ${ }^{-1}$ & 9.9 & 11.1 \\
\hline Sodium $(\mathrm{Na}), \mathrm{kg} \cdot \mathrm{ha}^{-1}$ & 265.1 & 317.3 \\
\hline Organic matter, \% & 4.0 & 4.3 \\
\hline
\end{tabular}

${ }^{\mathrm{z}}$ Average of three samples.
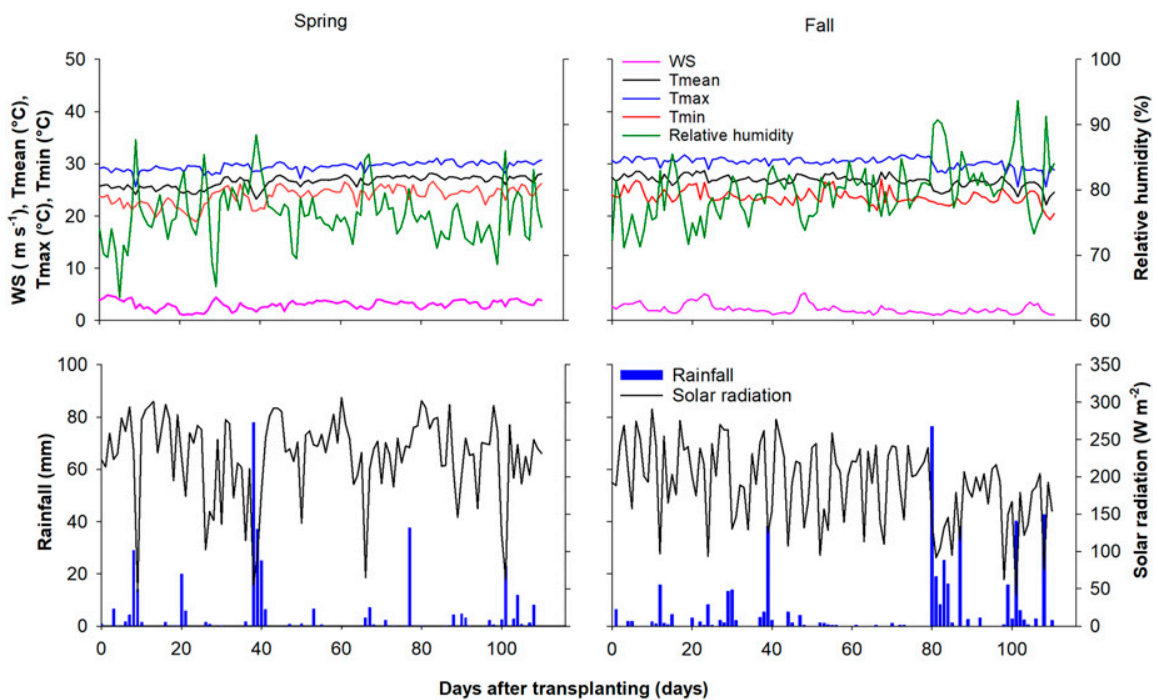

Fig. 1. Daily wind speed (WS), air temperatures [mean (Tmean), maximum (Tmax), and minimum (Tmin)], air relative humidity, rainfall, and solar radiation during the experiments performed in Spring (left) and Fall (right) 2016. Kingshill, U.S. Virgin Islands.

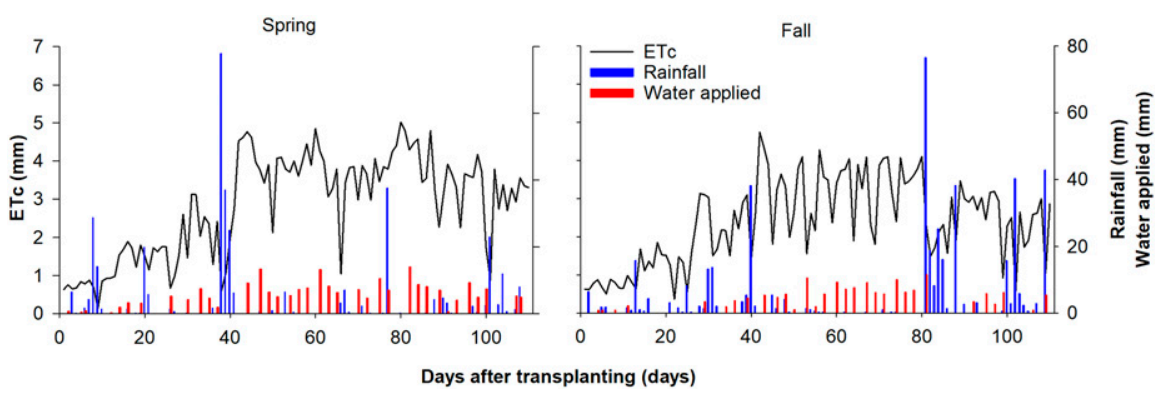

Fig. 2. Crop evapotranspiration (ETc) calculated by the American Society of Civil Engineers (ASCE) Environment and Water Resources Institute (EWRI) standardized Penman-Monteith equation (ASCEPM), rainfall and water applied in Spring (left) and Fall (right) 2016. Kingshill, U.S. Virgin Islands. 
line (heavy wall drip line) and one drip tape (thin wall drip tape) with pressurecompensating emitters and two drip tapes with noncompensating emitters (flow control drip tape and thin wall drip line); all were from different manufacturers. Equipment was selected based on water flow to provide the same amount of water to all treatments.

Cultural practices and plant material. The experimental area had been used for bell peppers preceding the first planting. The crop was ended by mowing followed by two passes with a disc harrow and two passes with a rototiller. To improve soil health before the okra trials, the field was planted with a cover crop in Fall 2015 using 'IAC-1' sunn hemp (Crotalaria juncea) $(800,000$ plants/ha). Sunn hemp seeds were inoculated with Bradyrhizobium sp. inoculant before planting. The cover crop was ended $90 \mathrm{~d}$ after planting by mowing with a rotary mower/shredder.

Okra seeds were sown in 72-cell trays on 19 Feb. 2016 (Spring) and 25 July 2016 (Fall). Transplants were fertigated with a starter fertilizer $(12 \mathrm{~N}-48 \mathrm{P}-8 \mathrm{~K}$ Plant Agra; Two-Way Trading Co, Headland, AL). Seedlings were transplanted to the field on 23 Mar. 2016 (Spring) and 11 Aug. 2016 (Fall). Each experimental unit had 30 plants, separated into three $3.05-\mathrm{m}$ rows with 10 plants each, totaling 360 plants per variety and 1080 per trial. Plants were spaced $0.3048 \mathrm{~m}$ in-row $\times$ $1.2192 \mathrm{~m}$ between-row (representing 26,909 plants/ha).

Table 2. Crop development stages, length in days, and crop coefficient $(\mathrm{Kc})$ values in Spring and Fall 2016. Kingshill, U.S. Virgin Islands. ${ }^{z}$

\begin{tabular}{lccccc}
\hline & \multicolumn{2}{c}{ Spring } & & \multicolumn{2}{c}{ Fall } \\
\cline { 2 - 3 } \cline { 5 - 6 } Stage & Length (days) & $\mathrm{Kc}$ & & Length (days) & $\mathrm{Kc}$ \\
\hline 1 & 13 & 0.2 & & 12 & 0.2 \\
2 & 14 & 0.4 & & 14 & 0.4 \\
3 & 14 & 0.7 & & 14 & 0.7 \\
4 & 51 & 1.0 & 51 & 1.0 \\
5 & 18 & 0.9 & & 20 & 0.9 \\
Total & 110 & - & 111 & -
\end{tabular}

${ }^{\mathrm{z}} \mathrm{Kc}$ values for the initial stage $(0.2-0.4)$, midstage (1.0), and late-stage (0.9). Adapted from Kisekka et al. (2019).
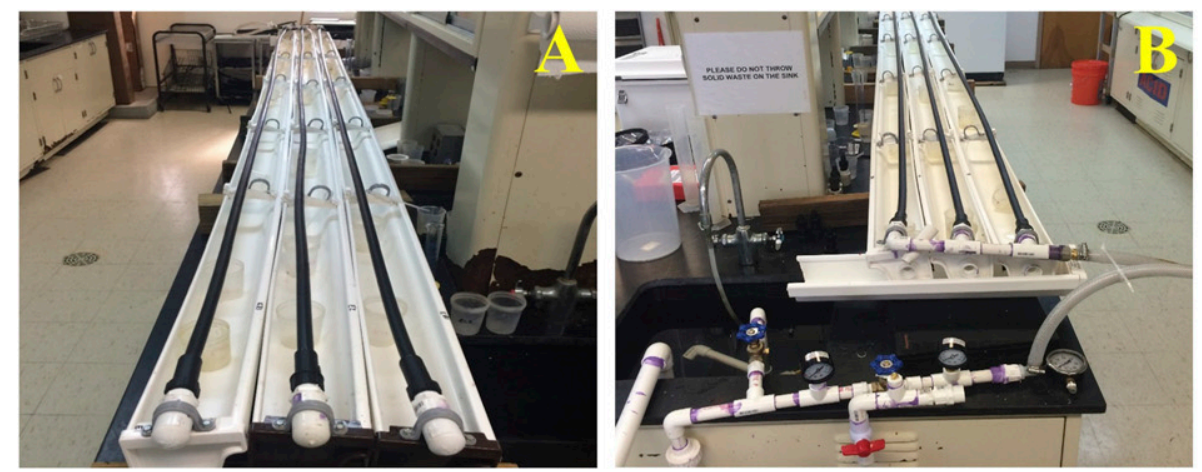

The fields were scouted for insect pests and plant diseases weekly until the first harvest, and then at every harvest. Lepidoptera (Lepidoptera sp.) was controlled using $\mathrm{Ba}$ cillus thuringiensis (DiPel DF; Valent Biosciences, Walnut Creek, CA) and spinosad (Entrust SC; Corteva, Wilmington, DE). Aphids (Aphidoidea) and leaf miner (Liriomyza sativae) were controlled using paraffinic oil (Agri-Dex; Helena Chemical, Collierville, TN), a pyrethrin-based spray (PyGanic Crop Protection EC 1.4II; McLaughlin Gormley King, Minneapolis, $\mathrm{MN}$ ), and neem oil (Trilogy; Certis USA, Columbia, MD). Powdery mildew was controlled using copper sulphate pentahydrate (Phyton 35; Phyton Corporation, New Hope, $\mathrm{MN})$. Weeds were manually controlled at 55, 66, and 88 DAT (Spring) and 30 DAT (Fall). To reduce the need for manual weeding, a 15-cm-thick layer of hay was spread on the field at 61 DAT (Spring) and 37 DAT (Fall).

Irrigation. The irrigated area had two submain lines to feed the 36 individual experimental units. The trials were arranged on a $35 \times 16 \mathrm{~m}$ rectangular field. Each experimental unit was $3.05 \mathrm{~m}$ long and $3.6576 \mathrm{~m}$ wide, with three lines, and it had an $83-\mathrm{kPa}$ pressure regulator, except for the plots with flow control drip tape, which needed a $69-\mathrm{kPa}$ pressure regulator to achieve the desired flow rate, and an irrigation manifold built using 1inch $(2.54 \mathrm{~cm}) \mathrm{PVC}$ pipe connected to three 3.05-m long lines of drip tape/tubing with $1.02 \mathrm{~L}$ per emitter and $30-\mathrm{cm}$ spacing. The area had a dedicated $3780-\mathrm{L}$ water tank attached to a 1/2-HP booster pump with a 22.7-L pressure tank (94525; Everbilt, Wilmington, DE) to guarantee stable pressure throughout the trials.

Reference evapotranspiration (ETo) was calculated from the environmental data by the American Society of Civil Engineers (ASCE) Environment and Water Resources Institute (EWRI) standardized PenmanMonteith (ASCE-PM) equation [American Society of Civil Engineers (ASCE) Environment and Water Resources Institute (EQRI), 2005]. Irrigation was performed based on the ETo and water balance method. Crop evapotranspiration was calculated by multiplying the ETo by the crop coefficient (Kc) (Fig. 2). Crop development stages, their duration, and Kc values are presented in Table 2.

Fertigation. The fertilizer solution was based on the soil nutrient analysis and okra nutritional requirements. The concentrated stock solution was prepared with a commercial soluble fertilizer (Jack's Professional 20N-20P-20K; Peters, Allentown, PA) and applied as $112 \mathrm{~kg} \cdot \mathrm{ha}^{-1} \mathrm{~N}$ (final concentration of $100 \mathrm{mg} \cdot \mathrm{L}^{-1} \mathrm{~N}$ ) using a fertilizer injector (D45RE15; Dosatron, Clearwater, FL).

Laboratory measurements. The irrigation equipment water flow responses to increasing pressure using clean water and three different slopes were evaluated in an experimental module assembled in the laboratory using three 6.1-m-long roof gutters (Fig. 3A and B) attached to a $1 / 2$-HP booster pump (maximum pressure of $462 \mathrm{kPa}$ ) with a $22.7-\mathrm{L}$ pressure tank (94525; Everbilt) (Fig. 3C). We used a 6.1-m-long irrigation line with emitters spaced $0.3048 \mathrm{~m}$ apart. The setup used calibrated pressure gauges to precisely monitor the applied pressure (Fig. 3B)

Incoming pressure was increased up to the maximum recommended by the manufacturer (flow control drip tape from 21 to 186 $\mathrm{kPa}$ in multiples of $21 \mathrm{kPa}$; thin wall drip tape from 28 to $280 \mathrm{kPa}$ in multiples of $28 \mathrm{kPa}$; heavy wall drip line from 41 to $414 \mathrm{kPa}$ in multiples of $41 \mathrm{kPa}$; and thin wall drip line from 14 to $152 \mathrm{kPa}$ in multiples of $14 \mathrm{kPa}$ ).

The emitter evaluation was performed at the beginning, one-quarter, one-half, threequarters, and at the end of the line. In each position, the water flow was measured in three sequential emitters for $3 \mathrm{~min}$ (Borssoi et al., 2012). Tests were repeated three times and in three different leveling conditions (leveled, uphill, and downhill) to simulate field conditions. For the uphill and downhill tests, the slope used was at $20 \%$ and the level difference was $1.22 \mathrm{~m}$ from the beginning to the end of the lateral lines.

Field measurements. The lateral lines were evaluated in the field to determine the irrigation system efficiency. We measured the water flow in 16 emitters per subunit (four lateral lines and four emitters per lateral line) using catch cans at the initial position, onequarter, one-half, three-quarters, and at the

Fig. 3. Experimental module designed and installed to evaluate the effects of increasing operational pressures on drip irrigation equipment water flow. (A) Overview of the testing plot with gutters, drip irrigation lines, and beakers to measure flow. (B) View of the recirculating system assembled to measure incoming pressure. (C) Irrigation pump and pressure tank. Kingshill, U.S. Virgin Islands. 
end of each line (Keller and Bliesner, 1990). With the emitter water flow information, we determined the Christiansen uniformity co-

Table 3. Irrigation efficiency parameters classification according to the ASABE (1994) and ASABE (2001) standards. Kingshill, U.S. Virgin Islands.

\begin{tabular}{|c|c|c|}
\hline \multirow[b]{2}{*}{ Classification } & CUC & CUD \\
\hline & \multicolumn{2}{|c|}{ 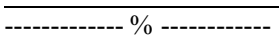 } \\
\hline Excellent & $>90$ & $>84$ \\
\hline Good & $80-90$ & $68-84$ \\
\hline Fair & $70-80$ & $52-68$ \\
\hline Poor & $60-70$ & $36-52$ \\
\hline Unacceptable & $<60$ & $<36$ \\
\hline
\end{tabular}

efficient (CUC) (Eq. [1]) and the distribution uniformity coefficient (CUD) (Eq. [2]) (Borssoi et al., 2012). The coefficients were classified according to the American Society of Agricultural Engineers (ASABE) standards available at ASABE (1994) and ASABE (2001) (Table 3).

$$
\mathrm{CUC}=100 \cdot\left[1-\frac{\sum_{\mathrm{i}=1}^{\mathrm{n}}\left|\mathrm{x}_{\mathrm{i}}-\overline{\mathrm{x}}\right|}{\mathrm{n} \cdot \overline{\mathrm{x}}}\right]
$$

where $\mathrm{n}=$ number of samples, $\mathrm{x}_{\mathrm{i}}=$ water depth applied to the $\mathrm{n}^{\text {th }}$ point on the soil surface, and $\overline{\mathrm{x}}=$ average water depth applied (considering all catch cans).

$$
\text { CUD }=100 \cdot \frac{\mathrm{x}}{\overline{\mathrm{x}}}
$$

where $\mathrm{x}=$ average water depth applied to the $25 \%$ lowest volumes of the catch cans.

Soil volumetric water content, soil temperature, and bulk EC were monitored to evaluate potential differences under the driplines using 36 capacitance sensors (24 10HS and 12 GS3; Decagon Devices, Pullman, WA) installed at a depth of $\approx 20 \mathrm{~cm}$ in the soil. The monitoring system was built using a data logger (CR1000; Campbell Scientific), multiplexer (AM16/32B; Campbell Scientific), and the capacitance sensors. The controller was powered using a $20-\mathrm{W}$ solar panel
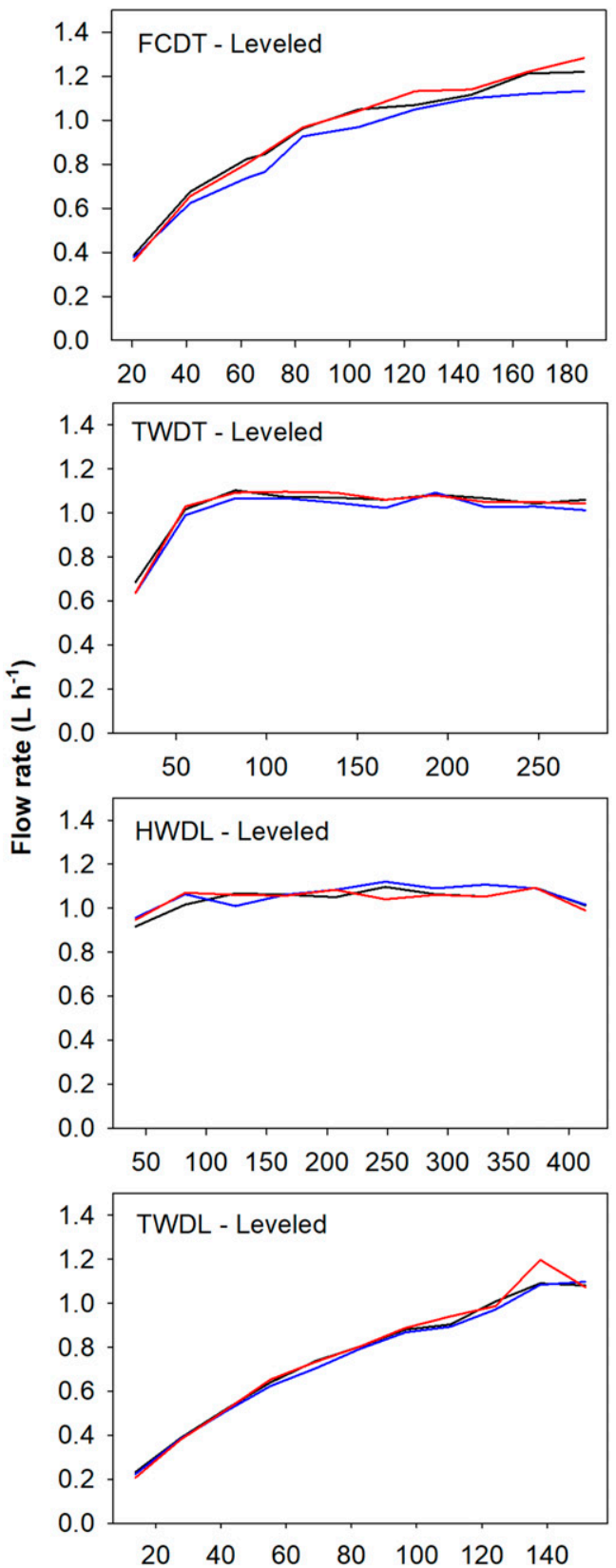
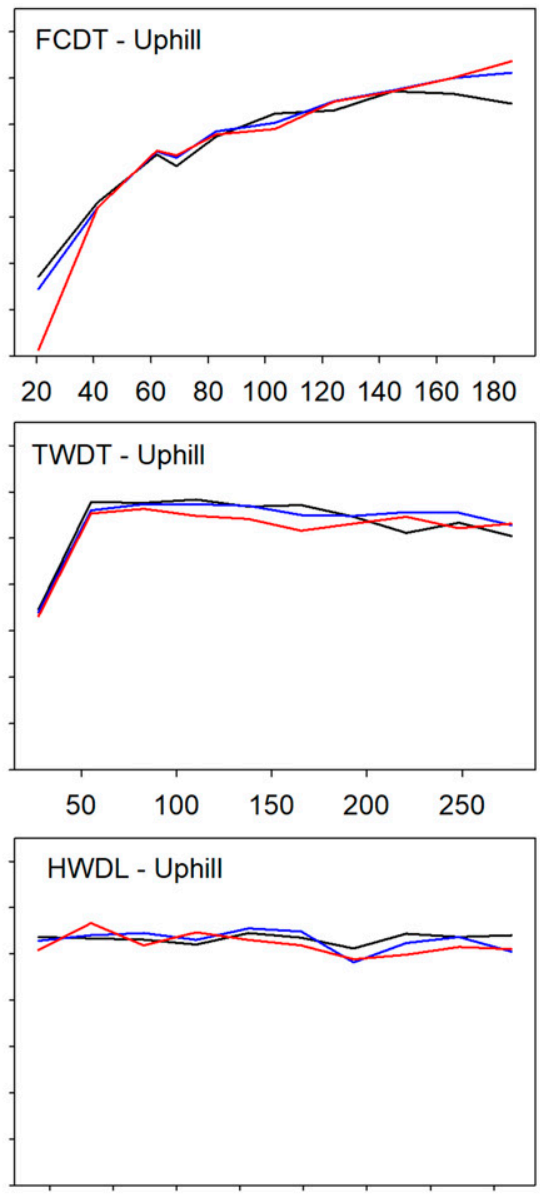

50100150200250300350400

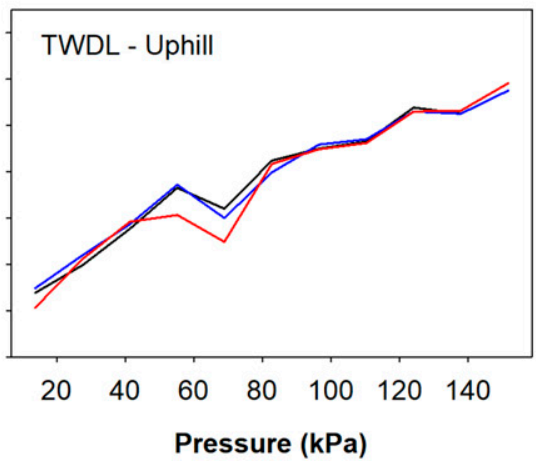

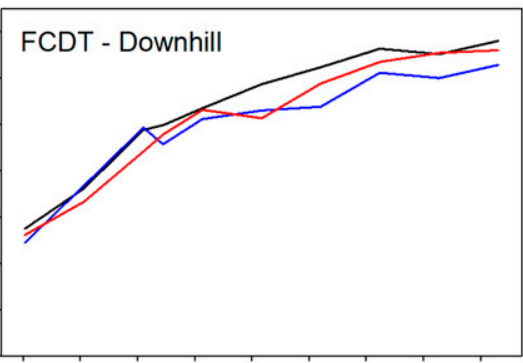

$20 \quad 40 \quad 60 \quad 80 \quad 100 \quad 120140160 \quad 180$
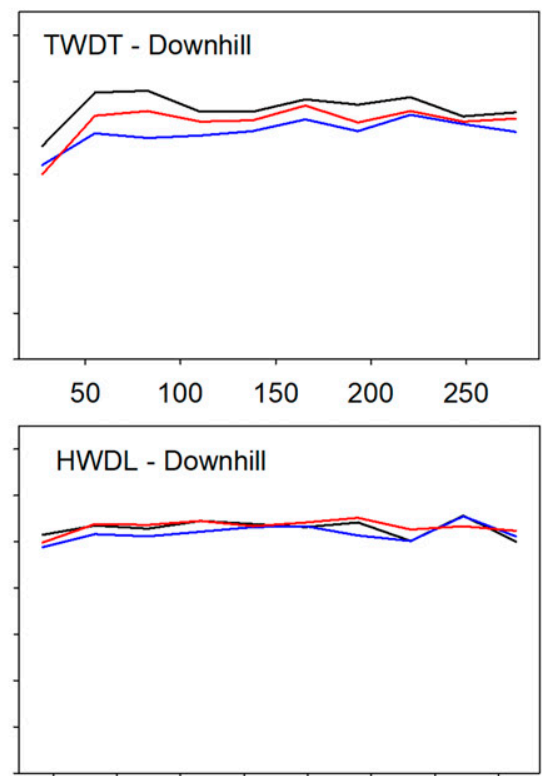

50100150200250300350400

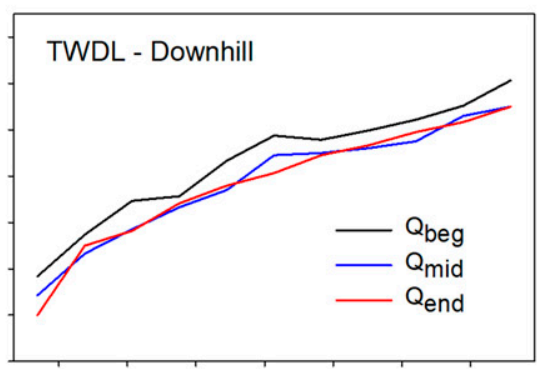

$20 \quad 40 \quad 60 \quad 80 \quad 100 \quad 120 \quad 140$

Fig. 4. Emitter flow rate of four types of drip irrigation equipment: flow control drip tape (FCDT; $1.02 \mathrm{~L} \cdot \mathrm{h}^{-1}$ at $69 \mathrm{kPa}$ according to the manufacturer's catalogue); thin wall drip tape (TWDT; $0.98 \mathrm{~L} \cdot \mathrm{h}^{-1}$ at $83 \mathrm{kPa}$ ); heavy wall drip line (HWDL; $0.98 \mathrm{~L} \cdot \mathrm{h}^{-1}$ at $83 \mathrm{kPa}$ ); and thin wall drip line (TWDL; $0.94 \mathrm{~L} \cdot \mathrm{h}^{-1}$ at $83 \mathrm{kPa}$ ) subjected to increasing operational pressures under three conditions (leveled, uphill, and downhill). Kingshill, U.S. Virgin Islands. 
(Infinium; ML Solar, Campbell, CA) connected to a $12 / 24-\mathrm{V}$ direct current (DC) 10 -A solar charge controller (Tracer 1210RN; EPSolar, Beijing, China) and two 12-V DC 7.2-Ah rechargeable batteries (Yuasa, Ebbw Vale, United Kingdom). The data collected were transmitted to a computer using a radio frequency module (RF401A; Campbell Scientific). Radios sent the collected information to the computer using Omnidirectional 900 $\mathrm{MHz} 3 \mathrm{dBd}$ and Yagi $900 \mathrm{MHz} 9 \mathrm{dBd}$ antennas (both from Campbell Scientific).

Total and marketable yields were determined weekly and totaled at the end of the cropping season. Leaf anthocyanin and chlorophyll content indexes (nondestructive analysis) were measured in Spring (day 108) and Fall (day 103). Anthocyanin was measured with a portable anthocyanin content meter (ACM-200 plus; Opti-Sciences, Hudson, $\mathrm{NH})$. Chlorophyll was measured using a chlorophyll concentration meter (MC-100; Apogee Instruments, Logan, UT). Plant growth index [(height + width $1+$ width 2$) / 3$ ], fruit size (weight, length, and width), and fruit hardness were measured using a digital penetrometer (FHP-802; Agriculture Solutions, Strong, ME). Fruit soluble solids content were measured using a refractometer (RF15; Extech Instruments, Nashua, NH) on day 100 (Spring) and day 103 (Fall).

Experimental design and statistical analysis. The experiment was arranged on a complete randomized block design with 12 treatments and three replications (36 experimental units). Data were analyzed using a mixed model procedure in SAS (version 9.4; SAS Institute, Cary, NC). Errors were assumed to be normally and independently (NID) distributed. The mean values were compared at Tukey's test at 5\% probability.

\section{Results and Discussion}

Laboratory measurements. The laboratory test provided water flow information under different conditions (leveled, uphill, and downhill). As expected, flow control drip tape and thin wall drip line (noncompensating emitters) increased water flow with increase in pressure (Fig. 4). Flow control drip tape presented a slight difference in the flow rate when working at low $(<30 \mathrm{kPa})$ or high $(>160 \mathrm{kPa})$ pressures for uphill installation when comparing measurements obtained at the beginning and the end of the lateral lines (Fig. 4). At low pressure $(21 \mathrm{kPa})$, the flow rate at the end of lateral lines was close to zero, which can be explained by the $1.22-\mathrm{m}$ difference in the level (equivalent to the 12.2$\mathrm{kPa}$ head loss), i.e., the pressure at the end of the lines was less than $8 \mathrm{kPa}$. That condition occurred due to the use of equidistant pressures to conduct the test using increasing values. In the real world, this condition only occurs when irrigators do not design the irrigation system properly. The manufacturer recommendation indicates the use of at least $30 \mathrm{kPa}$ for their equipment (Toro, 2019). During the downhill tests of this equipment, the flow rate at the end of the line was the same compared to that at the beginning, mainly due to the pressure gain (Fig. 4). For the thin wall drip line model, these differences in flow rates were observed for downhill installation only within the working pressure range (Fig. 4).

Thin wall drip tape and heavy wall drip line (pressure-compensating emitters) provided a steady water flow for pressure $>69$ $\mathrm{kPa}$ (Fig. 4). These results were expected because they were outlined by the equipment manufacturer. Pressure-compensating emitters also output the water discharge indicated by the manufacturer's catalogue at a given pressure; however, this did not occur with the noncompensating emitters. Our results clearly indicated that a more uniform water distribution can be achieved by replacing the noncompensating equipment with those with pressure-compensating emitters and using the equipment following the pressure range recommended by the manufacturer. This information is more relevant in regions with a limited water supply because the water application needs to have higher efficiency.

Regarding the cost of equipment, in 2017 , the flow control drip tape cost $\$ 0.24 / \mathrm{m}$, whereas thin wall drip line cost $\$ 0.08 / \mathrm{m}$, thin wall drip tape cost $\$ 0.15 / \mathrm{m}$, and heavy wall drip line cost $\$ 0.98 / \mathrm{m}$ (cost for the U.S. Virgin Islands with shipping included). Thin wall drip line is the least expensive equipment, whereas heavy wall drip line is the most expensive. Thin wall drip tape has been proven to be efficient, but the cost is almost double that of the most used equipment in the territory (thin wall drip line).

Field measurements. According to the ASABE standards for CUC (Table 3), all models were classified as good during the last evaluation in Spring 2016, and the thin wall drip line was the only one classified as excellent in Fall 2016. For CUD, flow control drip tape and thin wall drip line were classified as fair and the other models were classified as good during the last evaluation in Spring 2016, and all of them were classified as good during the last evaluation in Fall 2016, indicating that our systems met the efficiency requirements for drip irrigation to properly water the three okra varieties (Fig. 5). Efficiency decreased over time in Spring 2016 for flow control drip tape and thin wall drip line, probably due to clogging from suspended solids; however, during the last evaluation of Fall 2016, they were classified as good for both CUC and CUD. These coefficients represent how water is distributed to plants in the field. Equipment with $100 \%$ uniformity would indicate that all the plants would receive the same amount of water during each irrigation, which is directly related to their yield (Mantovani et al., 2012). However, measurements were taken in small plots, and the performance of these drip lines would change in larger fields with higher discharge variation.

Soil volumetric water content (Fig. 6A), soil temperature (Fig. 6B), and bulk EC (Fig. 6C) presented large variations in the tested treatments. Replication differences were expected and explained by the use of independent experimental units, variations in moisture caused by soil patches, sensor installation and position, and plant root interference, which were also reported by Ferrarezi and Testezlaf (2017). Data collected during Spring 2016 were consistently more stable than those collected during Fall

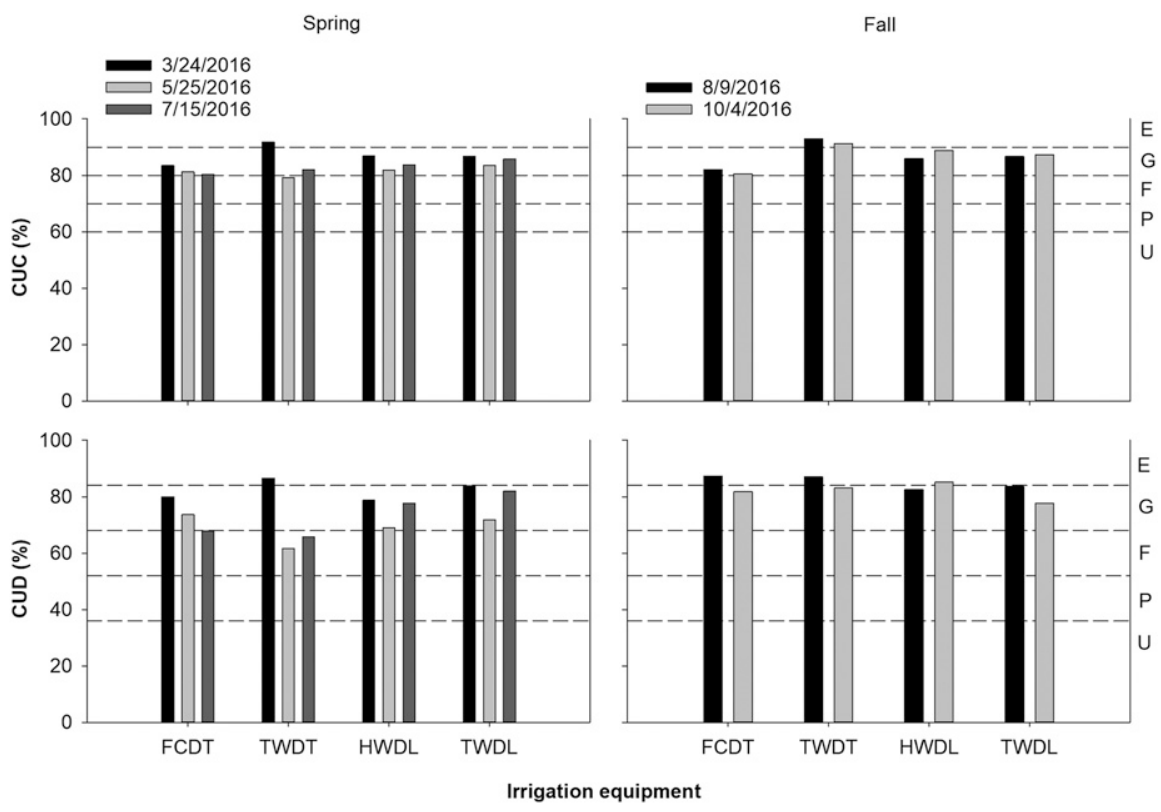

Fig. 5. Christiansen uniformity coefficient (CUC) and uniformity distribution coefficient (CUD) of drip irrigation equipment: flow control drip tape (FCDT; $1.02 \mathrm{~L} \cdot \mathrm{h}^{-1}$ at $69 \mathrm{kPa}$ according to the manufacturer's catalogue), thin wall drip tape (TWDT; $0.98 \mathrm{~L} \cdot \mathrm{h}^{-1}$ at $83 \mathrm{kPa}$ ); heavy wall drip line (HWDL; 0.98 $\mathrm{L} \cdot \mathrm{h}^{-1}$ at $83 \mathrm{kPa}$ ); and thin wall drip line (TWDL; $0.94 \mathrm{~L} \cdot \mathrm{h}^{-1}$ at $83 \mathrm{kPa}$ ). Classifications: E, excellent; G, good; F, fair; P, poor; and U, unacceptable. Kingshill, U.S. Virgin Islands. 


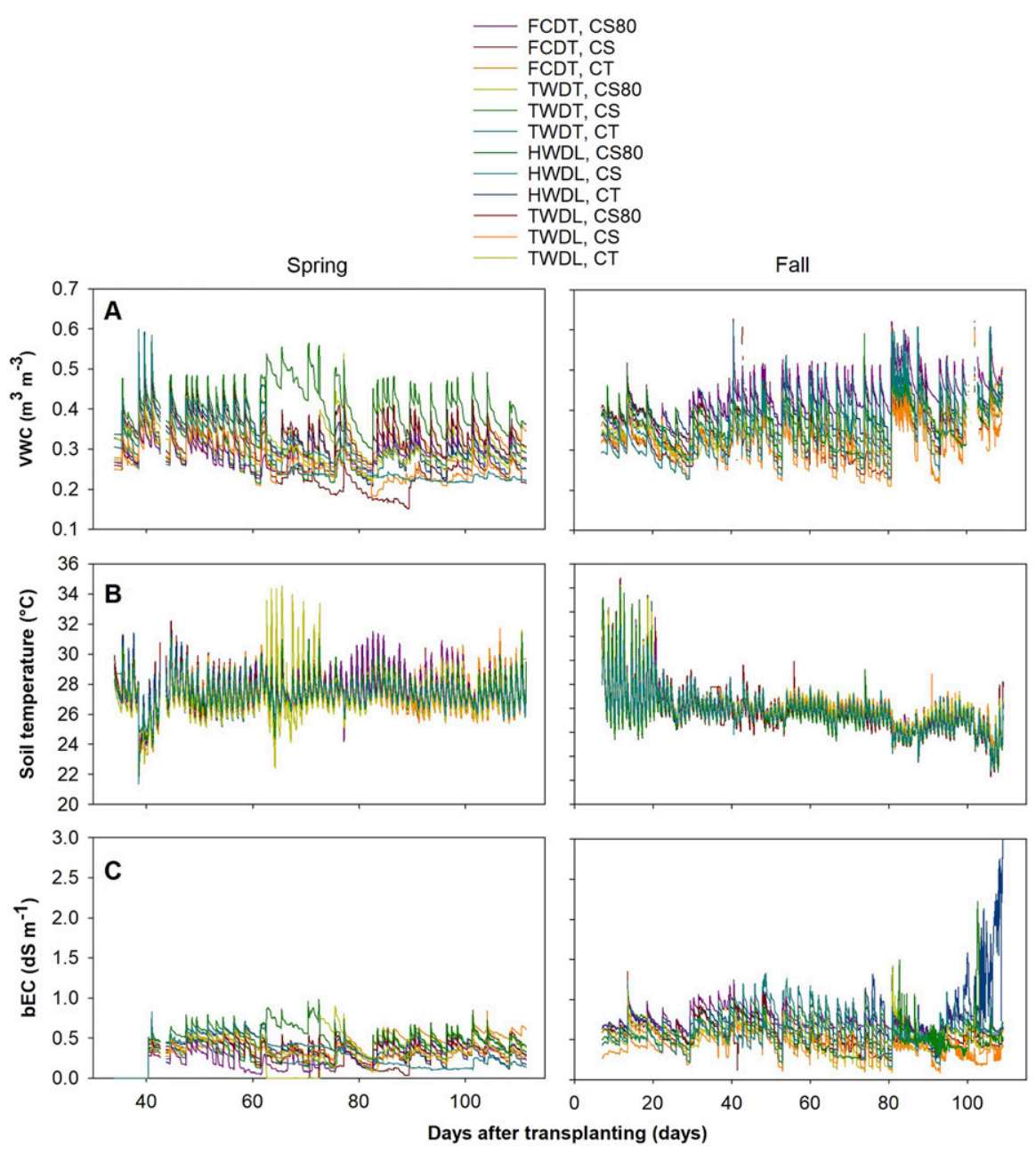

Fig. 6. Volumetric water content (A), soil temperature (B), and bulk electrical conductivity (bEC) $(\mathbf{C})$ monitored using capacitance sensors (10HS and GS3; Decagon Devices, Pullman, WA). Each sensor was positioned in a treatment combination using four types of drip irrigation equipment: flow control drip tape (FCDT; $1.02 \mathrm{~L} \cdot \mathrm{h}^{-1}$ at $69 \mathrm{kPa}$ according to the manufacturer's catalogue); thin wall drip tape (TWDT; $0.98 \mathrm{~L} \cdot \mathrm{h}^{-1}$ at $83 \mathrm{kPa}$ ); heavy wall drip line (HWDL; $0.98 \mathrm{~L} \cdot \mathrm{h}^{-1}$ at $83 \mathrm{kPa}$ ); and thin wall drip line (TWDL; $0.94 \mathrm{~L} \cdot \mathrm{h}^{-1}$ at $83 \mathrm{kPa}$ ). Three okra varieties were used: 'Clemson Spineless 80' (CS80); 'Clemson Spineless' (CS); and 'Chant' (CT). Kingshill, U.S. Virgin Islands.
2016. The reason for such variation is probably due to the greater precipitation. In Fall 2016, the sensors malfunctioned during the last $10 \mathrm{~d}$ because of an unidentified technical problem, which produced unrealistic measurements.

Total and marketable yield as well the percentage of marketable yield and leaf anthocyanin, were influenced by seasons $(P<$ 0.05 , Table 4 ), producing $79 \%$ higher total yield and $87 \%$ higher marketable yield in Spring when compared to Fall. However, leaf anthocyanin was $12 \%$ higher in Fall in comparison with Spring. This possibly happened because of the higher bulk EC (Fig. 6) and lower solar radiation (Fig. 1) values observed in Fall 2016. These findings are similar to several other studies, such as Scott (2002), Dkhil and Denden (2012), Cheng et al. (2014), and Soubeyrand et al. (2014). Shahbaz et al. (2012) presented a threshold of 1.2 $\mathrm{dS} \cdot \mathrm{m}^{-1}$ for okra. On the other hand, Unlukara et al. (2008) established $3.48 \mathrm{dS} \cdot \mathrm{m}^{-1}$ as a maximum value for okra production without interfering in fruit yield; this value is more than double the bulk EC observed in our study $\left(1.5 \mathrm{dS} \cdot \mathrm{m}^{-1}\right)$. If we consider the lowest threshold, then it is possible that salinity influenced the yield values (total yield, marketable yield, and percentage of marketable yield). However, according to Winkel-Shirley (2002), the presence of anthocyanin in some parts of plants, mainly in leaves, may allow the plant to develop resistance to environmental stresses, such as salinity.

The equipment tested presented no significant influence on the evaluated data $(P>$ 0.05 , Table 4 ). These results were expected because the observed efficiency coefficient values (CUC and CUD) calculated for all tested models were almost the same (Fig. 5). One of the most important aspects to observe in irrigation equipment is the water distribution

Table 4. Total yield, marketable yield, percent marketable yield, leaf anthocyanin, leaf chlorophyll, and plant growth index of three varieties of okra ('Clemson Spineless 80', 'Clemson Spineless', and 'Chant') cultivated during two seasons (Spring and Fall 2016) using four types of irrigation equipment. Kingshill, U.S. Virgin Islands. ${ }^{2}$

\begin{tabular}{|c|c|c|c|c|c|c|}
\hline & $\begin{array}{l}\text { Total yield } \\
\text { (kg/ha) }\end{array}$ & $\begin{array}{l}\text { Marketable yield } \\
(\mathrm{kg} / \mathrm{ha})\end{array}$ & $\begin{array}{l}\text { Marketable } \\
\text { yield }(\%)\end{array}$ & $\begin{array}{l}\text { Leaf anthocyanin } \\
\text { (ACI) }\end{array}$ & $\begin{array}{l}\text { Leaf chlorophyll } \\
\text { (CCI) }\end{array}$ & $\begin{array}{l}\text { Plant growth } \\
\text { index }(\mathrm{cm})\end{array}$ \\
\hline Spring 2016 & $27,315 \pm 7,101 \mathrm{a}$ & $20,843 \pm 5,368 \mathrm{a}$ & $76.36 \pm 4.26 \mathrm{a}$ & $10.46 \pm 1.80 \mathrm{~b}$ & $17.09 \pm 4.05$ & $102.51 \pm 5.63$ \\
\hline Fall 2016 & $15,267 \pm 5,305 b$ & $11,125 \pm 4,540 \mathrm{~b}$ & $68.40 \pm 5.61 \mathrm{~b}$ & $11.91 \pm 1.34 \mathrm{a}$ & $19.89 \pm 3.30$ & $104.73 \pm 8.54$ \\
\hline FCDT & $22,360 \pm 8,090$ & $16,567 \pm 5,845$ & $73.06 \pm 5.07$ & $11.49 \pm 1.43$ & $18.70 \pm 3.47$ & $105.37 \pm 7.13$ \\
\hline TWDT & $20,086 \pm 7,339$ & $14,732 \pm 5,384$ & $71.42 \pm 5.22$ & $10.15 \pm 1.59$ & $19.83 \pm 4.79$ & $102.51 \pm 7.64$ \\
\hline HWDL & $22,856 \pm 7,043$ & $17,731 \pm 6,573$ & $72.21 \pm 6.71$ & $11.32 \pm 1.36$ & $19.23 \pm 3.69$ & $104.69 \pm 9.00$ \\
\hline Clemson Spineless 80 & $20,788 \pm 7,893$ & $15,309 \pm 6,080$ & $70.41 \pm 6.04 b$ & $10.98 \pm 1.24$ & $17.39 \pm 2.56$ & $103.78 \pm 5.79$ \\
\hline Clemson Spineless & $23,121 \pm 7,531$ & $16,741 \pm 5,748$ & $69.96 \pm 4.41 \mathrm{~b}$ & $11.24 \pm 1.96$ & $17.18 \pm 2.65$ & $100.82 \pm 6.30$ \\
\hline Chant & $19,963 \pm 6,047$ & $15,901 \pm 5,429$ & $76.76 \pm 5.11 \mathrm{a}$ & $11.34 \pm 1.68$ & $20.91 \pm 5.18$ & $106.26 \pm 9.07$ \\
\hline \multicolumn{7}{|c|}{$P$ value } \\
\hline Season (S) & $0.0002 *$ & $0.0001 *$ & $0.0003 *$ & $0.0312 * *$ & 0.0549 & 0.4837 \\
\hline Equipment (E) & 0.8436 & 0.7663 & 0.9426 & 0.3198 & 0.3038 & 0.8384 \\
\hline $\mathrm{S}^{*} \mathrm{E}$ & 0.9609 & 0.8507 & 0.3952 & 0.5584 & 0.1810 & 0.7128 \\
\hline
\end{tabular}

${ }^{\mathrm{z}}$ flow control drip tape (FCDT; $1.02 \mathrm{~L} \cdot \mathrm{h}^{-1}$ at $69 \mathrm{kPa}$ according to the manufacturer's catalogue), thin wall drip tape (TWDT; $0.98 \mathrm{~L} \cdot \mathrm{h}^{-1}$ at $\left.83 \mathrm{kPa}\right)$, heavy wall drip line (HWDL; $0.98 \mathrm{~L}^{-1}$ at $83 \mathrm{kPa}$ ), and thin wall drip line (TWDL; $0.94 \mathrm{~L}^{-1}$ at $83 \mathrm{kPa}$ ).

*, **Significant at $P<0.01$ or 0.05 , respectively. 
Table 5. Fruit weight, fruit length, fruit width, fruit hardness, and fruit soluble solids content of three varieties of okra cultivated in two seasons (Spring and Fall 2016) and using four types of irrigation equipment. Kingshill, U.S. Virgin Islands. ${ }^{z}$

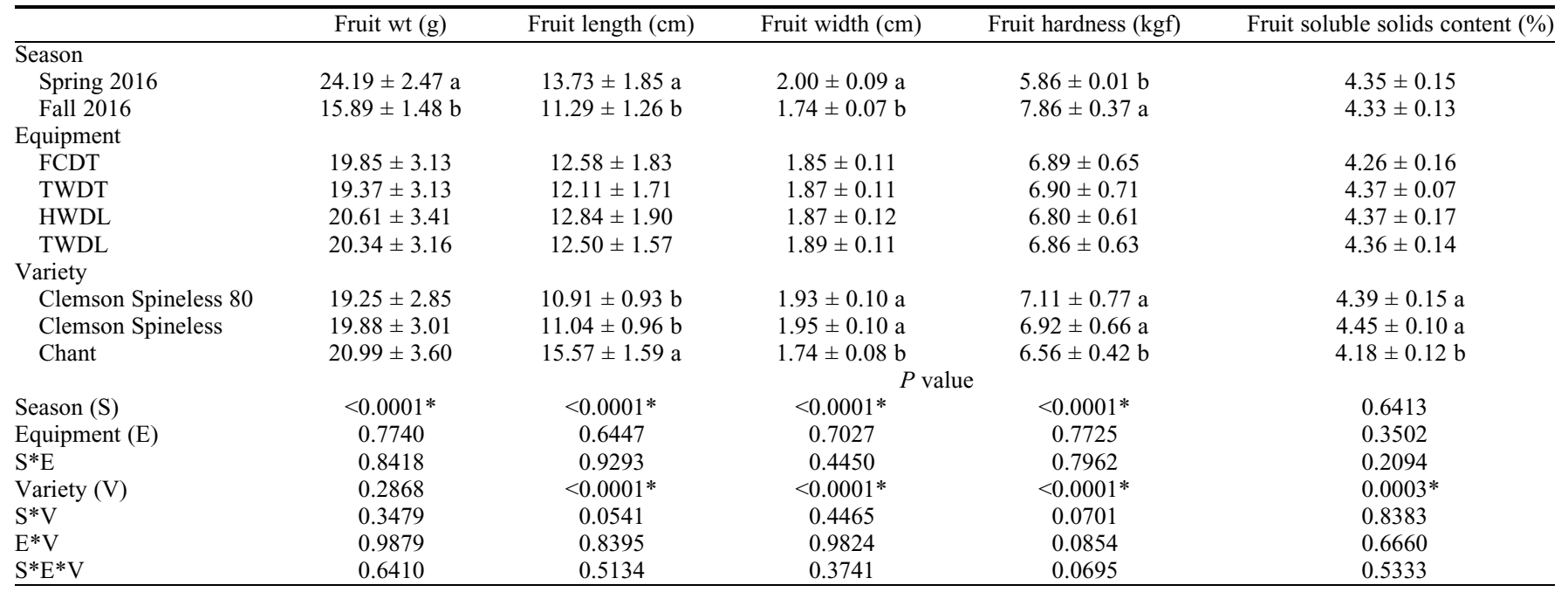

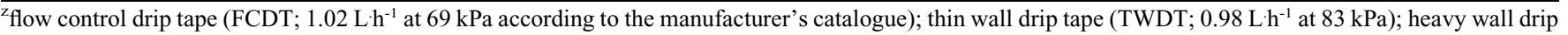
line (HWDL; $0.98 \mathrm{~L}^{-1}$ at $83 \mathrm{kPa}$ ); and thin wall drip line (TWDL; $0.94 \mathrm{~L}^{-1}$ at $83 \mathrm{kPa}$ ).

*Significant at $P<0.01$.

uniformity (Jensen, 2007) because low values can cause reductions in crop yield (Frizzone et al., 2007; Mantovani et al., 2012). Although the emitter's flow rates can differ slightly between emitters due to the manufacturing processes, the irrigation equipment were chosen based on similar flow rates and applied virtually the same amount of water during each irrigation event for all treatments.

The percentage of marketable yield was influenced by variety $(P<0.05$, Table 4$)$. 'Chant' presented the highest value (23.12 t.ha ${ }^{-1}$ ), which was $9 \%$ higher than the other varieties. Gordon et al. (2010) indicated that the okra yield can be up to $21.4 \mathrm{t} \cdot \mathrm{ha}^{-1}$ under field conditions. Our values were similar, indicating the ability to produce commercial yields in this environment. In fact, our yield was much higher than that of other studies: $11.46 \mathrm{t} \cdot \mathrm{ha}^{-1}$ (Akanbi et al., 2010), $15.98 \mathrm{t} \cdot \mathrm{ha}^{-1}$ (Dilruba et al., 2009), $19.00 \mathrm{t} \cdot \mathrm{ha}^{-1}$ (Tiendrébéogo et al., 2010), $19.22 \mathrm{t} \cdot \mathrm{ha}^{-1}$ (Firoz, 2009), and 19.24 t.ha ${ }^{-1}$ (Mann et al., 2009). We did not observe differences among the varieties trialed for the total yield and marketable yield, leaf anthocyanin, leaf chlorophyll, and plant growth index $(P>0.05$, Table 4$)$. We did not find any significant interactions between season and equipment, season and variety, equipment and variety, or season, equipment, and variety $(P>0.05$, Table 4$)$.

Fruit morphological parameters (length, width, and hardness) and soluble solids content were variety-dependent $(P<0.01$, Table 5). 'Clemson Spineless 80' and 'Clemson Spineless' had greater fruit width and hardness, as well as higher fruit soluble solids content. 'Chant' produced longer fruit, and this attribute could be responsible for its higher marketable yield percent (Table 4). We believe the same explanation can be used for the yield results. The greater salinity values in Fall compared with those in Spring might be the reason for the lower fruit weight, length, and width observed during this season. There were no significant factor interactions for morphological attributes $(P>0.05$, Table 5).

\section{Conclusions}

The pressure-compensating emitters maintained water flow within the range indicated by the manufacturers when operating at the recommended pressure range. Distribution uniformity decreased over time in all equipment except the heavy wall drip line in Fall 2016. Equipment should be selected based on price and irrigation efficiency to reduce the amount of water used. Irrigation equipment did not impact okra morphological attributes or total and marketable yields, indicating that the same productivity can be successfully maintained while improving irrigation efficiency. 'Chant' had the highest marketable yield of the varieties tested, with the highest yield observed in Spring 2016.

\section{Literature Cited}

Akanbi, W.B., A.O. Togun, J.A. Adediran, and E.A.O. Ilupeju. 2010. Growth, dry matter and fruit yields components of okra under organic and inorganic sources of nutrients. AmericanEurasian J. Sustainable Agr. 4(1):1-13.

American Society of Agricultural Engineers (ASABE). 1994. Design and installation of microirrigation systems (EP405.1). ASABE Standard Engineering Practices Data, St. Joseph, MI.

American Society of Agricultural Engineers (ASABE). 2001. Field evaluation of micro irrigation Systems (EP 458). ASABE Standard Engineering Practices Data, St. Joseph, MI.

American Society of Civil Engineers (ASCE) Environment and Water Resources Institute (EWRI). 2005. The ASCE standardized reference evapotranspiration equation. In: R.G. Allen, I.A. Walter, R. Elliott, T. Howell, D. Itenfisu, and M. Jensen (eds.). ASCE-EWRI
Task committee report. American Society of Civil Engineers, Reston, VA.

Borssoi, A.L., M.A. Vilas Boas, M. Reisdörfer, R.H. Hernández, and F.A. Follador. 2012. Water application uniformity and fertigation in a dripping irrigation set. Eng. Agr. 32:718-726.

Burt, C., A. Clemmens, T. Strelkoff, K. Solomon, R. Bliesner, L. Hardy, T. Howell, and D. Eisenhauer. 1997. Irrigation performance measures: Efficiency and uniformity. J. Irrig. Drain. Eng. 123(6):423-442.

Cheng, G., Y. He, T. Yue, J. Wang, and Z. Zhang. 2014. Effects of climatic conditions and soil properties on cabernet sauvignon berry growth and anthocyanin. Molecules 19(9):13683-13703.

Dilruba, S., M. Hasanuzzaman, R. Karim, and K. Nahar. 2009. Yield response of okra to different sowing time and application of growth hormones. J. Hort. Sci. \& Ornamental Plants 1(1):10-14.

Dkhil, B.B. and M. Denden. 2012. Effect of salt stress on growth, anthocyanins, membrane permeability and chlorophyll fluorescence of okra (Abelmoschus esculentus L.) seedlings. Amer. J. Plant Physiol. 7:174-183.

Dogan, E. and H. Kirnak. 2010. Water temperature and system pressure effect on drip lateral properties. Irrig. Sci. 28(5):407-419.

Eshiet, A.J. and E.A. Brisibe. 2015. Morphological characterization and yield traits analysis in some selected varieties of okra (Abelmoschus Esculentus L. Moench). Adv. Crop Sci. Technol. 3(5):1-5.

Ferrarezi, R.S. and R. Testezlaf. 2017. Automated ebband-flow subirrigation for citrus liners production. I. Plant growth. Agr. Water Mgt. 192:45-57.

Ferrarezi, R.S., S.A. Weiss, T.C. Geiger, and K.P. Beamer. 2016. Edible-pod peas as high-value crops in the U.S. Virgin Islands. HortTechnology 26:683-689.

Firoz, Z. 2009. Impact of nitrogen and phosphorus on the growth and yield of okra (Abelmoschus esculentus L. Moench) in hill slope condition. Bangladesh J. Agr. Res. 34(4):713-722.

Frizzone, J.A., R. Rezende, A.C.A. Gonçalves, and A. Hebel Júnior. 2007. Dry bean yield under different uniformity of water distribution on soil surface and undersurface. Eng. Agr. 27(2):414-425. 
Gordon, G.G., W.G. Foshee, S.T. Reed, J.E. Brown, and E.L. Vinson. 2010. The effects of colored plastic mulches and row covers on the growth and yield of okra. HortTechnology 20:224-233.

Jensen, M.E. 2007. Beyond irrigation efficiency. Irr. Sci. 25:233-245.

Keller, J. and R.D. Bliesner. 1990. Sprinkle and trickle irrigation. Van Nostrand Reinhold, New York, NY

Kisekka, I., K.W. Migliaccio, M.D. Dukes, J.H. Crane, B. Schaffer, S.M. Guzman, and H.K. Bayabil. 2019. Evapotranspiration-based irrigation for agriculture: Crop coefficients of some commercial crops in Florida. University of Florida Institute of Food and Agricultural Sciences (IFAS) Electronic Data Information Source (EDIS) document AE456. < http://edis.ifas.ufl.edu/ pdffiles/AE/AE45600.pdf $>$.

Mann, J.S., H.S. Jat, V. Kumar, S. Kumar, O.H. Chaturvedi, S. Saha, D. Kumar, and B.L. Bhaka. 2009. A participatory approach to improve the economic condition of resource poor farmers in semi-arid regions of Rajasthan, India. SAARC J. Agr. 7(1):1-10.

Mantovani, E.C., D.R.P. Montes, G.H.S. Vieira, M.M. Ramos, and A.A. Soares. 2012. Estimated production of bean crop irrigated in CristalinaGO under different depths and uniformity of application. Eng. Agr. 32(1):110-120.

Palada, M.C., S.M.A. Crossman, and C.D. Collingwood. 1995. Improving vegetable production using microirrigation in the Virgin Islands. Proc. Intl. Microirrigation Congr. 5:502-509.

Pereira, L.S., T. Oweis, and A. Zairi. 2002. Irrigation management under water scarcity. Agr. Water Mgt. 57:175-206.

Pereira, L.S., I. Cordery, and I. Iacovides. 2012. Improved indicators of water use performance and productivity for sustainable water conservation and saving. Agr. Water Mgt. 108:39-51.

Scott, L.C. 2002. Do anthocyanins function as osmoregulators in leaf tissues? Adv. Bot. Res. 37:103-127.

Shahbaz, M., M. Ashraf, F. Al-Qurainy, and P.J.C. Harris. 2012. Salt tolerance in selected vegetable crops. Crit. Rev. Plant Sci. 31:303-320.

Silva, C.A. and C.J. Silva. 2005. Uniformity performance assessment in localized irrigation system. Revista Cientifica Eletrônica de Agronomia 1(8):1-17.

Soubeyrand, E., C. Basteau, G. Hilbert, C. van Leeuwen, S. Delrot, and E. Gomès. 2014.
Nitrogen supply affects anthocyanin biosynthetic and regulatory genes in grapevine cv. Cabernet Sauvignon berries. Phytochemistry 103:38-49.

Testezlaf, R. 2011. Irrigation: Methods, systems and applications. UNICAMP, Campinas, SP, Brazil.

Tiendrébéogo, F., E.V.S. Traoré, J.M. Lett, N. Barro, G. Konaté, A.S. Traoré, and O. Traoré. 2010. Impact of okra leaf curl disease on morphology and yield of okra. Crop Prot. 29:712-716.

Toro. 2019. Toro superior drip tape. The Toro Company, El Cajon. 1 Oct. 2019. <https://cdn2. toro.com/en/-/media/Files/Toro/Agriculture/ drip-tape-and-dripline/ALT230_FamilyBrochure_ ENG_WEB_170410.ashx>.

Unlukara, A., A. Kurunc, G.D. Kesmez, and E. Yurtseven. 2008. Growth and evapotranspiration of okra (Abelmoschus esculentus L.) as influenced by salinity of irrigation water. ASCE J. Irr. Drain. Eng. 134:160-166.

U.S. Department of Agriculture (USDA). 2015. Web soil survey. 18 Sept. 2015. <http:// websoilsurvey.nrcs.usda.gov>.

Winkel-Shirley, B. 2002. Biosynthesis of flavonoids and effects of stress. Curr. Opin. Plant Biol. 5(3):218-223. 